\title{
International Registration of Cultivar Names for Unassigned Woody Genera 1995
}

\author{
Steven E. Clemants ${ }^{1}$ \\ Brooklyn Botanic Garden, 1000 Washington Avenue, Brooklyn, NY 11225-1099, USA
}

\begin{abstract}
During 1995, nine cultivar names in unassigned woody genera were registered. Photos and herbarium specimens, where indicated, have been deposited in the Brooklyn Botanic Garden Herbarium. Anyone who is involved in originating or introducing new cultivars of ornamental plants is urged to assure that the names are registered with a view to nomenclatural stabilization. A list of the International Registration Authorities is available from the American Association of Botanical Gardens and Arboreta, 786 Church Rd., Wayne, PA 19087, USA.
\end{abstract}

Acer saccharinum 'Silver Cloud'. Registered 3 Oct. 1995. Registrants: Rick Durand, Prairie Shade Consulting Services, 89 Wilkenson Crescent, Portage la Prairie, MB R1N 1A7, Canada, and Wilbert Ronald, Jeffries Nurseries, Box 402 Portage la Prairie, MB R1N 3B7, Canada. Acer saccharinum 'Silver Cloud' has an upright, oval form with narrower branch angles and compact crown compared to 'Northline', which has wider branch angles and its crown is much more open-headed and loose. It is considered hardy to U.S. Dept. of Agriculture zone 3.

Atriplex lentiformis 'Playa'. Registered 3 July 1995. Registrant: Gwen Meyer, horticulturist, National Plant Materials Center, Building 509, BARC-East, Beltsville, MD 20705. The origin of the plant is unknown. The Tucson Materials Center received the plant from the Agricultural Research Service (ARS) Plant Introduction Center, Beltsville, Md. ARS received seed from Israel via Venezuela. Atriplex lentiformis 'Playa' demonstrated the highest rates of establishment and growth under arid conditions and has been selected as the best candidate for revegetation of critical areas and riparian habitats of the arid southeastern U.S. deserts. A specimen has been deposited at the U.S. National Arboretum. More information is available in the U.S. Dept. of Agriculture's Notice of Naming and Release of 'Playa' Quailbush (Atriplex lentiformis).

Exochorda serratifolia 'Northern Pearls'. Registered 3 Oct. 1995. Registrant: Harold Pellett, Minnesota Landscape Arboretum, P.O. Box 39, 3675 Arboretum Dr., Chanhassen, MN 55397. Pellett selected this plant from a seedling population from the Beijing Botanic Garden. It has a somewhat more upright and regular growth habit than the species. It is considered hardy to U.S. Dept. of Agriculture zone 4a. A valid description and photograph can be found in Landscape Plant News [5(3):16; Oct. 1994].

Lonicera pileata 'Loughall Evergreen'. Registered 6 July 1995. Registrant: Daphne Purdy, N. Ireland Horticulture and Plant Breeding Station, Manor House, Loughgall, Armagh BT61 8JB, United King-

${ }^{1}$ Taxonomist, Brooklyn Botanic Garden, and registrar for unassigned woody genera. dom. This cultivar was selected from clonal material at Loughgall; the origin of the original material is unknown. This clone remains mostly evergreen and has shoots that tend to layer readily so that the resulting form can be quite hummocky and widespread. It also flowers and fruits readily. It is considered an ideal groundcover plant.

Lonicera tatarica 'Honey Rose'. Registered 3 Oct. 1995. Registrant: Harold Pellett, Minnesota Landscape Arboretum, P.O. Box 39, 3675 Arboretum Dr., Chanhassen, MN 55397. Pellett developed this cultivar from a cross between $L$. tatarica 'Zabelii' and $L$. tatarica 'Arnold Red'. This cultivar is resistant to witches broom aphid and has a deeper rose-red flower color than the species. A description and photograph can be found in Landscape Plant News [4(2):10; June 1993].

Parthenocissus quinquefolia 'Dark Green Ice'. Registered 3 July 1995. Registrant: Jean-Pierre Devoyault, 1070 1er Rang Ouest, Ste-Christine, Que. J0H 1H0, Canada. Devoyault selected this plant from the wild for its dark-green glossy foliage that does not turn red in the fall (if grown in shady locations). It is hardy to Canadian zone $2 \mathrm{~b}$. A valid description with photographs appeared in Quebec Vert, Québec's horticultural professional magazine, Jan. 1994 (note: 'Dark Green Ice' is incorrectly cited as a trademark in this publication).

Sorbus aria 'Ottery'. Registered 3 July 1995. Registrant: N.R. Phillips, Noor Farm, Yeovil Rd., Nether Compton, Sherborne, Dorset DT9 4PX, England. Phillips selected this plant in 1990 from a cross between $S$. aria 'Lutescens' and $S$. aria 'Majestica'. It is a wellproportioned tree of distinctive appearance, branching freely and uniformly. The growth is more shapely than 'Lutescens' (more upright and vigorous), but appearance in spring is less silvery. Leaves much less prone to browning and premature abscission than 'Lutescens'. The growth is less vigorous, sparser, and coarser than 'Majestica'. It is hardy to at least Arnold Arboretum zone 8 and has done well in light soils.

Tilia cordata 'Golden Cascade'. Registered 6 July 1995. Registrant: Wilbert G. Ronald, Jeffries Nurseries, P.O. Box 402, Portage la Prairie, MB R1N 3B7, Canada. This cultivar is similar to $T$. cordata Norlin ('Ronald') but with cascading branches, globe-shaped crown, and golden foliage in the fall. It grows in moist, well-drained loam and clay loam in semi-protected areas and is considered hardy to zone $2 \mathrm{~b}$ of the Canadian Plant Hardiness Map.

Tilia mongolica 'Harvest Gold'. Registered 6 July 1995. Registrant: Wilbert G. Ronald, Jeffries Nurseries, P.O. Box 402, Portage la Prairie, MB R1N 3B7, Canada. This cultivar was selected for its upright form, excurrent growth, exfoliating bark, and consistent goldenyellow fall color. It is adapted to moist, well-drained loam and clay loam in semi-protected areas and is considered hardy to zone $2 \mathrm{~b}$ of the Canadian Plant Hardiness Map. 